\title{
Pills, Polls, and Professors Redux
}

\author{
Martin Lipton $\dagger$
}

September of this year will mark the twentieth anniversary of the publication of my memorandum recommending that companies adopt the poison pill, which I invented in the summer of 1982 to deal with the takeover abuses that emerged in the 1970s and had become endemic by the end of the decade. The pill prevents a hostile tender offer from being consummated unless and until the board of directors of the target redeems the pill. The pill does not prevent a proxy fight to remove and replace a board of directors that refuses to redeem the pill. It was and is a fundamental aspect of the pill that a proxy fight is the only way in which a raider can override a well-founded decision of the board to reject and block a takeover bid. Now Professor Lucian Bebchuk urges, in his brilliantly presented Article, that basic state corporation law be changed to allow a raider to demand a shareholder referendum whenever a board refuses to redeem a pill. ${ }^{1}$ This proposal is one of several that have been advanced over the years to deny the board of a target the ability to craft a strategy to protect corporate interests in the context of a hostile takeover bid. In a rough chronological sequence, the pro-takeover, anti-board-of-directors arguments have been:

(1) The law should deny the board the power to be anything but passive in the face of a takeover bid. ${ }^{2}$

$\dagger$ Partner, Wachtell, Lipton, Rosen \& Katz, New York City. I am grateful to my colleagues Laura A. McIntosh, Erin E. Quinn, and Paul K. Rowe for their significant contributions to this Commentary, and to William T. Allen, Andrew R. Brownstein, John A. Elofson, Daniel A. Neff, Gregory N. Racz, Eric S. Robinson, Steven A. Rosenblum, William D. Savitt, Warren R. Stern, Herbert M. Wachtell, and Jeffrey M. Wintner for their helpful comments. Portions of this Commentary have been adapted from Martin Lipton and Paul K. Rowe, Pills, Polls, and Professors: A Reply to Professor Gilson, 27 Del J Corp L (forthcoming 2002).

1 See Lucian Arye Bebchuk, The Case Against Board Veto in Corporate Takeovers, $69 \mathrm{U}$ Chi L Rev 973 (2002). See also Lucian Arye Bebchuk and Allen Ferrell, $A$ New Approach to Takeover Law and Regulatory Competition, 87 Va L Rev 111 (2001) (proposing an optional body of federal takeover law to help overcome the shortcomings of state takeover law).

2 See Frank H. Easterbrook and Daniel R. Fischel, The Proper Role of a Target's Management in Responding to a Tender Offer, 94 Harv L Rev 1161, 1194-95 (1981) (arguing that the business judgment rule should never justify a decision to oppose a tender offer). 
(2) The law should deny the board the power to frustrate the takeover bid, but permit the board to advise the shareholders as to fairness and to seek a higher bid. ${ }^{3}$

(3) The pill is illegal.

(4) A pill should require shareholder approval before it is effective.

(5) Shareholders can initiate and adopt a bylaw amendment that forces redemption of the pill and precludes adoption of a pill. ${ }^{6}$

(6) Given that at least Delaware will probably hold that the shareholder bylaw overruling the pill is not legal, shareholders should initiate and adopt bylaw amendments that do not directly

3 See Lucian Arye Bebchuk, Comment, The Case for Facilitating Competing Tender Offers, 95 Harv L Rev 1028, 1054 (1982) (concluding that, while management should not obstruct tender offers, it should be allowed to look for other buyers and provide them information to facilitate competing bids); Ronald J. Gilson, A Structural Approach to Corporations: The Case Against Defensive Tactics in Tender Offers, 33 Stan L Rev 819, 865-67 (1981) ("By providing information [to shareholders], management facilitates shareholder comparison of the value of the target securities with the value of the tender offer."). See also European Parliament and Council Directive on Company Law Concerning Takeover Bids (joint text approved by the Conciliation Committee on June 5,2001).

4 See Amalgamated Sugar Co v NL Industries, Inc, 644 F Supp 1229, 1234 (S D NY 1986) (holding that a flip-in provision violated a New Jersey law that prohibited discrimination among shareholders of the same class and series); Moran v Household International, Inc, 500 A2d 1346, 1356 (Del 1985) (rejecting the appellants' argument that the board of directors did not have the power to adopt the poison pill and that the board may not usurp shareholders' right to receive hostile tender offers); Bank of New York Co, Inc v Irving Bank Corp, 536 NYS2d 923 (NY Sup Ct 1988) (granting a preliminary injunction preventing the defendant from exercising a flip-in provision), affd, 533 NYS2d 412, 143 AD2d 1075 (1988). See also Robert A. Helman and James J. Junewicz, A Fresh Look at Poison Pills, 42 Bus Law 771, 772 (1987) ("[I]t is clear that postHousehold there has been a growing skepticism as to the appropriateness of using a poison pill plan to cut off shareholders from offers that might otherwise be made to acquire their stock at above-market prices.").

5 See Jeffrey N. Gordon, “Just Say Never?": Poison Pills, Deadhand Pills, and ShareholderAdopted Bylaws: An Essay for Warren Buffett, 19 Cardozo L Rev 511, 549 (1997) (arguing that shareholders should be able to adopt a bylaw that would establish a shareholder mechanism as a precondition for the effectiveness of the pill).

6 See International Brotherhood of Teamsters General Fund v Fleming Companies, Inc, 1999 OK 3, 975 P2d 907, 908 (concluding that Oklahoma state law allowed shareholders to propose bylaws that would restrict board implementation of shareholders-rights plans); Ronald J. Gilson, Unocal Fifteen Years Later (and What We Can Do about It) at 21-28, Columbia Law and Economics Working Paper No 177 (June 2000), available online at <http://papers.ssrn.com/ id=235417 > (visited Jan 31, 2002) ("[S]hareholder-adopted bylaws largely (but not entirely) returns [sic] to shareholders the decision making role with respect to tender offers that Household International transferred to the board of directors."); Gordon, 19 Cardozo L Rev at 549 (cited in note 5). 
overrule the pill, but make a takeover easier and takeover defense more difficult.'

(7) Professor Bebchuk's proposal to change the law to permit a bidder-initiated referendum to remove the pill and all other takeover defenses, which would be binding on all the shareholders if it received the support of a majority of the outstanding shares of the target. ${ }^{8}$

This Commentary discusses the development of the lawprimarily Delaware law-governing takeovers, and against that background, rebuts Professor Bebchuk's referendum proposal. In a way, this Commentary is the culmination of my efforts over a twenty-year period in courts, legislatures, and academic publications to counter those who would hang a permanent "For Sale" sign on all public companies. I have sought to preserve the ability of the board of directors of a target of a hostile takeover bid to control the target's destiny and, on a properly informed basis, to conclude that the corporation remain independent. I have never been able to understand the persistent refusal of those academics who would hang a "For Sale" sign on public corporations to recognize: (i) that there are very significant costs to corporations in being managed as if they are continuously for sale; and (ii) that there is simply no evidence at all that the damage, if any, that the anti-pill academics attribute to the pill is greater than those costs.

Prior to the 1960 s, there was little academic discussion or judicial or legislative focus on the legal rules that should apply to the response by a corporation to a takeover bid. With the increase in takeover activity in the 1970s, the topic became a growing concern for lawyers who advised target corporations, but there was neither direct, cogent case law nor meaningful academic debate. From the outset, it was clear that there were three constituencies with prime interests in any rule-shaping debate: (i) the shareholders, (ii) the corporation as an operating entity, and (iii) the employees and other stakeholders. Within each group, there were gradations of interests, and the groups and interests overlapped and sometimes collided. In this period, the role of the board of directors and the grounds on which it was to act in responding to a hostile takeover bid were nebulous and had yet to be definitively determined.

7 See John C. Coates IV and Bradley C. Faris, Second-Generation Shareholder Bylaws: Post-Quickturn Alternatives, 56 Bus Law 1323, 1335 (2001) ("If shareholder bylaws are to have a significant role in the future, they will need to be designed to do something other than effectively overrule Moran's legalization of poison pills.").

8 See text accompanying note 74. 
In an effort to distill clarity from this confusion, in 1979 I wrote what became the seminal article in the ensuing debate. In Takeover Bids in the Target's Boardroom,' I argued, based on my experience during the 1960s and 1970s in advising boards of directors of corporations that were the targets of hostile takeover bids, that the directors should be governed by the business judgment rule and that in exercising their judgment they should be able to take into account the interests of employees, communities, and other constituents, as well as the long-term (and not just the short-term) interests of the shareholders.

This position was quickly rejected by academics opposed to an active board role in the hostile takeover context, who argued for the so-called "Rule of Passivity," relegating directors to the role of passive observers proscribed from any action other than giving advice to the shareholders. A classic series of articles ensued, ${ }^{10}$ with the courts deciding the debate in favor of the business judgment rule." This exchange

9 Martin Lipton, Takeover Bids in the Target's Boardroom, 35 Bus Law 101, 130 (1979) (outlining in detail the proper role for a board facing a takeover bid).

10 See, for example, Bebchuk, Comment, 95 Harv L Rev at 1054 (cited in note 3) (arguing that although incumbent management should be barred from actions that obstruct any tender offer, management should diligently seek a higher offer); Frank H. Easterbrook and Daniel R. Fischel, Takeover Bids, Defensive Tactics, and Shareholders' Welfare, 36 Bus Law 1733, 1745-46 (1981) (arguing that decisions as to tender offers do not involve management of the corporation's affairs in any meaningful sense and can be made by the shareholders); Easterbrook and Fischel, 94 Harv L Rev at 1199-1201 (cited in note 2) (defending their proposal of director passivity in response to tender offers by distinguishing between the board's role in tender offers and its role in other situations); Martin Lipton, Takeover Bids in the Target's Boardroom: An Update after One Year, 36 Bus Law 1017, 1021-26 (1981) (reemphasizing the importance of the procedures used by the board in considering a takeover bid); Gilson, 33 Stan L Rev at 878-79 (cited in note 3) (arguing that in the face of a tender offer, management of the target company should take no action other than to (1) disclose information bearing on the value or attractiveness of the offer, and (2) seek out alternative transactions which it believes may be more favorable to target shareholders); Leo Herzel, et al, Why Corporate Directors Have a Right to Resist Tender Offers, 3 Corp L Rev 107, 109-10 (1980) (arguing that board resistance to a tender offer may benefit shareholders by driving up the price); Martin Lipton, Takeover Bids in the Target's Boardroom: A Response to Professors Easterbrook and Fischel, 55 NYU L Rev 1231, 1233 (1980) ("As long as the economic benefits of takeovers are debatable, rejection or acceptance of a tender offer should continue to be left to the business judgment of the target's board."); Martin Lipton and Andrew Brownstein, Takeover Responses and Directors' Responsibilities: An Update, ABA Natl Inst on the Dynamics of Corp Control 7 (Dec 1983) (noting that boards must consider the nature of a takeover bid and its effect on the corporate enterprise, including the adequacy of the price, the nature and timing of the offer, the impact on constituencies other than shareholders, the risk of nonconsummation, and the quality of the securities being offered in the exchange). See also Martin Lipton, Takeover Abuses Mortgage the Future, Wall St J 16 (Apr 5, 1985) (claiming that the threat of hostile takeover forces companies to sacrifice long-term growth for short-term profitability); Martin Lipton, Boards Must Resist, NY Times $2 \mathrm{~F}$ (Aug 9, 1981) (criticizing Easterbrook and Fischel's analysis).

11 See Panter $v$ Marshall Field \& Co, 646 F2d 271, 293-95 (7th Cir 1981) (declining to apply a different test in the context of takeovers); Johnson v Trueblood, 629 F2d 287, 292-93 (3d Cir 1980) ("[W]e believe that under Delaware law, at a minimum the plaintiff must make a showing that the sole or primary motive of the defendant was to retain control."); Crouse-Hinds Co v ln- 
of articles reflected a fierce public policy debate. The new breed of hostile bids was, on the one hand, wreaking havoc with expectations of managers, employees, and communities, and, on the other, enriching the raiders and a new class on Wall Street: the bankers who advised, financed, or arbitraged takeovers. The pro-takeover forces found theoretical support for their position among a group of economists who adhered to the efficient market theory, which was argued to offer support for the proposition that shareholder wealth could be maximized by outlawing most forms of takeover defenses. Starting from the premise that share prices at all times accurately reflect the intrinsic value of a corporation, efficient market theory partisans contended that the willingness of a bidder to offer a premium price reflects the bidder's ability to manage the assets better or more efficiently. At the same time, they contended that board reluctance to accept a premium price necessarily reflects an instinct of self-preservation rather than conviction that the tender price is inadequate. Defenses, in this view, serve only to entrench incumbents and necessarily to harm shareholders.

The opponents of the efficient market theory pointed out that corporations were not chartered by the states solely to maximize shareholders' short-term gains, ${ }^{13}$ and that large corporations could not function in an environment where they were continuously "for sale." The aggregate costs to all shareholders of all public companies, if they had to operate on this basis, would far exceed the costs, if any, in the long-run to the shareholders of companies that successfully resist unsolicited takeovers. Those who did not accept the relevance of the efficient market theory to the regulation of takeovers also pointed out, drawing on a growing body of economic literature, that inefficiencies

terNorth, Inc, 634 F2d 690, 702-03 (2d Cir 1980) (noting that a complaining shareholder must present evidence of the directors' self-interest in order to shift the burden of proof to the board); Unocal Corp $v$ Mesa Petroleum Co, 493 A2d 946 (Del 1985) (concluding that the business judgment rule should apply when the board addresses a pending takeover bid); Kahn v MSB Bancorp, Inc, 1998 Del Ch LEXIS 112, *7 (applying the business judgment rule to the board's decision to reject a merger offer), affd, 734 A2d 158 (Del 1999).

12 See, for example, Easterbrook and Fischel, 94 Harv L Rev at 1182-83 (cited in note 2) (arguing that tender offers increase social welfare by moving productive assets to higher valued uses and to the hands of better managers).

13 For a very different view of the corporation, see Margaret M. Blair and Lynn A. Stout, A Team Production Theory of Corporate Law, 85 Va L Rev 247 (1999).

14 Corporation law is designed to protect the "long-term value of capital committed indefinitely to the firm," William T. Allen, Ambiguity in Corporation Law, 22 Del J Corp L 894, 896-97 (1997), and does not share the short-term horizon of takeover arbitrageurs. See also Martin Lipton and Steven A. Rosenblum, A New System of Corporate Governance: The Quinquennial Election of Directors, 58 U Chi L Rev 187, 189 (1991) (arguing "that the ultimate goal of corporate governance is the creation of a healthy economy through the development of business operations that operate for the long term and compete successfully in the world economy"). 
in the market could exist at any given point in time, meaning that share prices did not always reflect intrinsic values. ${ }^{15}$

Those in favor of takeover defenses further argued that a central assumption of efficient market theory proponents-that shareholder responses to tender offers are necessarily informed decisions that rationally reflect the supposed "best" interests of all shareholders collectively-is not true. Tender offers are not the functional equivalents of free votes, since the decision not to tender (whether into an all-cash, all-shares offer or a two-tier, front-end-loaded offer) carries with it economic risks and detriments; not knowing whether the mass of other shareholders will tender or not, the individual holder faces the classic "prisoner's dilemma" and is effectively stampeded into tendering. The proponents of takeover defenses also observed that many hostile bids were opportunistic attempts to buy assets on the cheap, and that there was no empirical evidence that such takeovers were always (or ever) good for the economy. ${ }^{16}$ Moreover, the view that directors were only capable of acting in their self-interest was unsupported by empirical evidence and inconsistent with the assumptions underlying the structure of American corporate law."

15 See Lipton and Rosenblum, 58 U Chi L Rev 198-99 (cited in note 14) (relying on this literature to criticize the efficient market theory).

16 See, for example, John Pound, The Promise of the Governed Corporation: The Limits of Economic Solutions, 73 Hary Bus Rev 89, 91 (1995) ("Many takeover bids themselves represent flawed decisions by the acquirer."); Martin Lipton, Corporate Governance in the Age of Finance Corporatism, U Pa L Rev 1, 23 (1987) ("The advent of the highly leveraged takeover, and the defensive responses to it, have forced companies to focus on short-term profitability rather than on capital investment, long-term planning, research, and development."); Richard L. Stern and Edward F. Cone, Scarlett O'Hara Comes to Wall Street, Forbes 37-38, 40 (Sept 21, 1987) (reporting competition to provide financing for leveraged acquisitions and suggesting that valuations were driven up to insupportable levels); Edson Spencer, The U.S. Should Stop Playing Poker with Its Future, Bus Week 20 (Nov 17, 1986) (arguing that Wall Street has adopted the view that "the higher the stock price, the better the management has done its job," leading managers "to put short-term earnings growth before such interests as market development, product quality, research and development, and customer and employee satisfaction"); Harold M. Williams, It's Time for a Takeover Moratorium, Fortune 136 (July 22, 1985) (commenting that takeover activity has resulted in a loss in management effectiveness that "works against corporate and national productivity, the wages of employees, and returns to stockholders. It undermines our economy and our society."); Jonathan P. Charkham, Keeping Good Company: A Study of Corporate Governance in Five Countries 219, 229 (Oxford 1994) (arguing that putting great emphasis on shareholders' immediate values may result in competitive disadvantage compared to other nations' systems that take a longer-term view). See also Allen D. Boyer, Activist Shareholders, Corporate Directors, and Institutional Investment: Some Lessons from the Robber Barons, 50 Wash \& Lee L Rev 977, 1004-05 (1993) (explaining that as LBOs increased and junk bonds became popular, a new group of investors entered and expanded the market for low-grade debt).

17 See, for example, 8 Del Code Ann $\$ 141$ (a) (1991) (providing that the business and affairs of every Delaware corporation shall be managed by a board of directors). This is an eminently sensible state of affairs; among other advantages, directors have much better (nonpublic) information and far lower costs of communication than do shareholders. 
State legislatures around the country resolved this debate squarely in favor of directorial discretion. Between 1968 and 1982, laws designed to slow or halt the wave of opportunistic takeover activity were enacted in thirty-seven states. ${ }^{18}$ Thus, by the early 1980 s, both the legislatures and the courts had emphatically rejected the view that directors should be passive in the face of takeover bids. ${ }^{19}$ But in 1982, by a razor-thin margin, the United States Supreme Court invalidated the "first generation" of antitakeover statutes in Edgar v MITE Corp. Now there was nothing to delay the consummation of a tender offer beyond the Williams Act's twenty business days. Increasingly, boards turned to creative attempts to release short-term value by selling pieces of the business or turning to a "white knight," but these alternative transactions were often difficult to achieve on the truncated timeline of the Williams Act minimum tender period.

The MITE decision coincided with the decision of most institutional investors that they would not vote for charter amendments designed to deter or regulate hostile takeovers and with the federal courts picking up on an earlier decision by Judge Henry Friendly in which he treated with great skepticism suits brought by targets raising antitrust, disclosure, and similar claims to enjoin hostile bids. ${ }^{2}$ This left the playing field heavily tipped in favor of the corporate raiders and peddlers of junk bonds. In September 1982, I published a memorandum describing the "Warrant Dividend Plan." Warrant Dividend Plan was a security that could be issued by the board of directors of a target company (before or after it was faced with an unsolicited bid) that would have the effect of increasing the

18 See Grant A. Gartman, State Takeover Laws Appendix B-5 (Investor Responsibility Research Center 2000).

19 See note 11 .

20457 US 624, 632-34 (1982) (plurality) (concluding that the Williams Act struck a careful balance between the interests of offerors and target companies, and that any state statute that "upset" this balance was preempted).

$21 \quad 15$ USC $\$ \$ 78 \mathrm{~g}, 781-78 \mathrm{n}, 78 \mathrm{~s}$ (1994).

22 See Missouri Portland Cement Co v Cargill, Inc, 498 F2d 851 (2d Cir 1974) (Friendly) (holding that the target of the tender offer had failed to demonstrate the probability of success on its antitrust claims against the potential acquirer). See also Scientific Computers, Inc v Edudata Corp, 599 F Supp 1092, 1098 (D Minn 1984) ("Nor should employee morale or an increase in management anxiety be a basis for injunctive relief"); American General Corp v NLT Corp, 1982 US Dist LEXIS 9690, *70 (S D Tex) (quoting Cargill for the statement that "district judges should take arguments of serious harm to a corporation due to jitters in executive suites with a fair amount of salt"); Raybestos-Manhattan Inc v Hi-Shear Industries, 503 F Supp 1122, 1134 (E D NY 1980) (citing Cargill for the proposition that "[ $\mathrm{t}] \mathrm{he}$ Second Circuit has warned district courts to look skeptically on Clayton Act claims raised by target management who become vigilant enforcers of the antitrust laws only when a tender offer threatens their control").

23 Martin Lipton, memorandum, Warrant Dividend Plan (Sept 15, 1982) (on file with author). 
time available to the board to react to an unsolicited bid and allowing the board to maintain control over the process of responding to the bid. Beginning at the end of 1982, in various forms it was used successfully by targets of hostile bids to gain time and maximize shareholder value. Six months later, in 1983, the plan was given its unfortunate nickname by an investment banker who had nothing to do with its creation. When asked by a Wall Street Journal reporter what to call a security-modeled on the Warrant Dividend Plan-issued on my advice by Lenox, Inc. to defend against a hostile tender offer, this banker responded flippantly, "a poison pill.",

By whatever name, the pill's arrival was remarkably timely. As the tide of junk-bond-financed, bootstrap bids, sometimes linked to two-tier, front-end-loaded tenders, rolled on in the mid-1980s, there was increasing recognition that something was needed to redress the balance between the corporate raider and the board of the target. The pill met precisely that need. Nevertheless, those who believed that directors should play no active role in the hostile takeover context viewed the introduction of the pill as a radical innovation, and the attacks on the pill's validity were unrelenting. ${ }^{25}$

The increasing use of the pill in 1984-85 set the stage for a decisive confrontation between the forces advocating a free hand for corporate raiders and those supporting the traditional model of the corporation and the business judgment rule. The question remained: Who would act as the decisionmaker? At the federal level, Congress had shown no interest in adopting a statutory framework for regulating takeovers beyond the Williams Act; and by 1983 the federal impulse for further regulation, even at the SEC level, had petered out. The United States Supreme Court in Santa Fe Industries, Inc $v$ Green $^{26}$ had extinguished the ability of federal judges to federalize substantive

24 Frank Allen and Steve Swartz, Lenox Rebuffs Brown-Forman, Adopts Defense, Wall St J 2 (June 16,1983) ("Lenox's strategy already is being referred to on Wall Street as 'the poison-pill defense." ).

25 See, for example, Helman and Junewicz, 42 Bus Law at 771 (cited in note 4) (suggesting that the poison pill may be invalid or financially inconsequential); Jonathan Shub, Shareholder Rights Plans-Do They Render Shareholders Defenseless against Their Own Management?, 12 Del J Corp L 991, 993 (1987) (arguing that a board's unilateral adoption of a poison pill usurps the right of shareholders to decide whether to sell their stock to a purchaser); Galvin Stevenson, A Poison Pill That's Causing a Rash of Lawsuits, Bus Week 54 (Apr 1,1985) (noting SEC opposition to the poison pill used in Household); Ralph C. Ferrara and William J. Phillips, Opposition to 'Poison Pill' Warrants Is Mounting, Legal Times 13 (Oct 15, 1984) (warning directors to do "some long, hard thinking" about poison pills before adoption); Kim Masters, Poison Pill Takeover Defense Stirs Controversy, Uncertainty, Legal Times 1 (Aug 29, 1983) (discussing whether the poison pill strategy is an effective antidote to two-tiered takeover bids).

26430 US 462 (1977). 
takeover law through the securities laws. ${ }^{27}$ On the other hand, the Court's opinion in MITE had limited the ability of state legislatures to impose their own statutory regulation in the area. ${ }^{23}$ Meanwhile, increasing corporate reliance on defensive tactics-and the increasingly shrill objections of their opponents-created a pressing practical need for dependable legal ground rules. The state courts were left as the only institutional actors with the power and will to fashion a comprehensive resolution.

In 1985, the Delaware Supreme Court decided four cases-Smith $v$ Van Gorkom, ${ }^{29}$ Unocal Corp v Mesa Petroleum Co, Revlon, Inc $v$ MacAndrews \& Forbes Holdings, ${ }^{31}$ and Moran v Household International, Inc ${ }^{32}$-that created the framework that has governed takeover law ever since. The key choices Delaware made in 1985 were the following:

(1) In Van Gorkom, Delaware decisively rejected the efficient market theory and not only permitted, but required, directors to make takeover-related decisions based on an informed view of the "intrinsic" value of the corporation-not the value assigned by the stock market. ${ }^{33}$

(2) In Unocal, citing with approval a later version of my 1979 article, Takeover Bids in the Target's Boardroom, ${ }^{34}$ Delaware accepted the utility and appropriateness of "takeover defenses" and the board of directors' discretion to deploy such defenses, but announced that henceforth they would be reviewed under an enhanced business judgment rule-a tougher and objective "rea-

27 Id at 479 ("Absent a clear indication of congressional intent, we are reluctant to federalize the substantial portion of the law of corporations that deals with transactions in securities, particularly where established state policies of corporate regulation would be overridden.").

28 See note 20 and accompanying text. The states were, however, active in reversing several federal court rulings that the pill was invalid under state corporate statutes. Every court ruling invalidating pills was legislatively overturned. See, for example, NY Bus Corp Law \$ 505(a)(2) (West 1990) (overturning a July 1988 New York State Supreme Court decision invalidating Irving Bank's flip-in poison pill, see Irving Bank, 536 NYS2d at 925-26); NJ Rev Stat Ann § 14A:77 (West Supp 2001) (overturning an August 1986 New York federal district court case applying New Jersey corporate law, which invalidated NL Industries' flip-in poison pill, see Amalgamated Sugar, 644 F Supp at 1234).

29488 A2d 858 (Del 1985).

$30 \quad 493$ A2d 946 (Del 1985).

31506 A2d 173 (Del 1986). The Delaware Supreme Court decided Revlon in 1985, although its opinion was issued in 1986.

32500 A2d 1346 (Del 1985).

33 See 488 A2d at 875-76 (referring to the use of only market price to determine that a premium was adequate as "faulty" and "fallacious").

34 See 493 A2d at 955, citing Lipton and Brownstein, Takeover Responses at 7 (cited in note 10). 
sonable in relation to the threat posed" test, rather than the preexisting subjective business judgment rule.

(3) In Revlon, Delaware required directors to maximize shortterm value once they decided to sell a company for cash; and conversely, Delaware decided that it would not require directors to maximize short-term value outside this one, relatively narrow situation. Delaware companies were not required to be for sale twenty-four hours a day, seven days a week, and directors could agree to friendly stock mergers without putting the company "in play" or having to "auction" the company.

(4) In Household, Delaware permitted boards to adopt the poison pill as a structural defense to a takeover bid. Household recognized that the pill gave boards the power to "just say no" until such time as the shareholders (if they so wished) replaced the incumbent directors, and established that judicial review of a board's use of the poison pill would be subject to the enhanced business judgment rule standard of Unocal. ${ }^{37}$

Clearly, these four crucial decisions represented a set of compromises. Delaware accepted neither the pleas of corporate constituencies for continued application of the deferential business judgment rule to takeover defense, nor endorsed the demands of corporate raiders and academics who sought to outlaw takeover defense. Instead, Delaware chose a middle ground: Takeover defenses were permitted, but they were to be judged, in common law fashion, under a fact-intensive, case-by-case analysis in which the directors would effectively bear the burden of showing not only their good faith, but also the "reasonableness" of their chosen response.

Put to the practical test during the half-decade of intense hostile takeover activity that ensued, the new Delaware paradigm has worked well. Contrary to the fears of both sides, Unocal and its siblings did not

35493 A2d at $954-55,957$.

36 See MacAndrews \& Forbes Holdings, Inc v Revlon, Inc, 501 A2d 1239, 1248 (Del Ch 1985) (referring to the use of only market price to determine that a premium was adequate as "faulty" and "fallacious"). Although this implication of Revlon was reasonably clear from the opinion, the efficient market partisans refused to acknowledge it as Delaware doctrine until the Delaware Supreme Court had the opportunity to make it an express holding four years later in Paramount Communications, Inc v Time Inc, 571 A2d 1140, 1150 \& n 12 (Del 1989) ("TimeWarner") (holding that a corporate board of directors "is not under any per se duty to maximize shareholder value in the short term, even in the context of a takeover"). Moreover, the court stated that "it is not a breach of faith for directors to determine that the present stock market price of shares is not representative of true value." Id.

37 See Household, 500 A2d at 1354. 
usher in a period in which every takeover defense was either condemned automatically or rubber-stamped. A review of some of the major cases of that period demonstrates the suppleness of the standard and the discriminating manner in which it was applied. ${ }^{33}$

Of the quartet of 1985 decisions, the one that proved to have the greatest practical impact was undoubtedly Household. ${ }^{39}$ The pill changed everything. Instead of twenty business days under the Williams Act, boards now had sufficient time to consider, respond to, and craft alternatives to unsolicited bids. And, contrary to the arguments of the plaintiffs in Household, ${ }^{40}$ the pill actually revived the importance of proxy contests as a means of determining a corporation's future. Indeed, the Delaware courts rarely receive the credit they deserve for having been right in rejecting the supposed factual, empirical arguments made by the pill's opponents in Household as to the predicted effect of the pill on proxy contests. Professors and experts were paraded in the Court of Chancery to testify, among other things, that validation of the pill in Delaware would suppress proxy contests." Both the Court of Chancery and the Delaware Supreme Court refused to let themselves be persuaded by these "experts"-and of course with hindsight we can see that the pill simply did not usher in the parade of horribles predicted by its opponents. As the Chancery Court correctly predicted, the pill did not spell the doom of proxy contests. ${ }^{42} \mathrm{~A}$ recent review of the economic literature on the shareholderwealth effects of takeover defenses was undertaken by Professor John Coates. ${ }^{43}$ He concluded:

38 See, for example, Ivanhoe Partners $v$ Newmont Mining Corp, 535 A2d 1334, 1344 (Del 1987) (upholding a special dividend issued to facilitate a "street sweep" to defeat a two-tier offer); Robert M. Bass Group, Inc v Evans, 552 A2d 1227, 1247 (Del Ch 1988) (enjoining restructuring adopted in response to unsolicited bid); AC Acquisitions Corp v Anderson, Clayton \& Co, 519 A2d 103, 115-16 (Del Ch 1986) (enjoining recapitalization adopted in response to hostile bid).

39 See Stevenson, Rash of Lawsuits, Bus Week at 58 (cited in note 25):

This is probably the single most important corporate law case to come before the courts in years. .. . Legal challenges [to the pill] have proliferated [throughout the United States].... But the [Household] case in Delaware is the crucial one. Because so many companies are incorporated there, and because the court is widely respected, its decision will set the tone for rulings in other state and federal courts.

40 Plaintiffs in Household, 500 A2d at 1355 , argued that the pill's restriction upon individuals or groups from first acquiring more than 20 percent of shares before waging a proxy contest would reduce the potency of proxy contests. Even the SEC filed an amicus curiae brief in support of this argument. Id at 1346,1351.

41 See Moran v Household International, Inc,490 A2d 1059, 1079 (Del Ch 1985).

42 See id at 1080 ("On the evidence presented it is highly conjectural to assume that a particular effort to assert shareholder views in the election of directors or revisions of corporate policy will be frustrated by the proxy feature of the Plan.").

43 John C. Coates IV, Empirical Evidence on Structural Takeover Defense: Where Do We Stand?, 54 U Miami L Rev 783 (2000). 
Delaware courts should take some comfort from the fact that they resisted strong academic arguments and political efforts that attempted to push them to dramatically repudiate pills and other structural defenses. The empirical case against defenses remains unproven, and, without empirical support, the theoretical case against defenses is not as compelling as it might have seemed to hostile commentators [in 1989]."

The new rules crafted by the Delaware courts in the four 1985 decisions met with wide acceptance. Corporate raiders did not abandon the market for corporate control, ${ }^{45}$ corporations did not seek to reincorporate out of Delaware in order to avoid the new regime; ${ }^{46}$ and litigators íncreasingly chose the Delaware state forum over federal and non-Delaware state courts when there was a need for adjudication. Interestingly, the pill even became a standard feature in initial public offering charters, a context in which management entrenchment is virtually absent. ${ }^{42}$

But the 1985 Delaware rules were controversial enough-and perceived as insufficiently sensitive to the realities of corporate lifeto provoke a legislative reaction in other states. It is a signal fact that, despite Delaware's primacy as a corporate domicile and despite some academic criticism of Delaware as too protective of management, ${ }^{4,}$ the

44 Id at 797. In view of this conclusion by Professor Coates, it is difficult to understand his seeming endorsement of shareholder-initiated bylaws that would curtail defenses against hostile takeovers. See Coates and Faris, 56 Bus Law at 1373 (cited in note 7).

45 The Delaware Supreme Court noted in Barkan v Amsted Industries, Inc, 567 A2d 1279, 1287 (Del 1989):

[T]he spate of takeover litigation ... readily demonstrates that such 'poison pills' do not prevent rival bidders from expressing their interest in acquiring a corporation.... Because potential bidders know that a pill may not be used to entrench management or to unfairly favor one bidder over another, they have no reason to refrain from bidding if they believe that they can make a profitable offer for control of the corporation.

46 See Robert Daines, Does Delaware Law Improve Firm Value? at 1, NYU Center for Law and Business Working Paper No 99-011 (1999), available online at <http://papers.ssrn.com/ id=195109> (visited Apr 30, 2002).

47 See Robert Daines and Michael Klausner, Do IPO Charters Maximize Firm Value? Antitakeover Provisions in IPOs, 17 J L, Econ, \& Org 83, 95 (2001) (reviewing charter provisions in over three hundred companies that went public between 1994 and 1997, and finding no single provision that prohibited or limited the use of poison pills).

48 There is a growing body of academics that views Delaware corporation law as, on balance, highly successful. See, for example, Marcel Kahan and Edward D. Rock, How I Learned to Stop Worrying and Love the Pill: Adaptive Responses to Takeover Law, 69 U Chi L Rev 871, 873 (2002) (stating that the pill helped contribute to a new equilibrium that "transformed the pill into a device that plausibly is in shareholders' interest and, in any event, one that shareholders can easily live with"); Daines, Does Delaware Law Improve Firm Value? at 35 (cited in note 46) ("On average and over time, investors pay more for the assets of publicly held firms governed by Delaware corporate law."); Marcel Kahan, Paramount or Paradox: Delaware Supreme Court's Takeover Jurisprudence, 19 J Corp L 583, 606 (1994) (characterizing Delaware law as "plausible 
Delaware regime has not been broadly embraced by the other states. Instead, a number of states enacted legislation that to a greater or lesser extent rejected the Delaware compromise as too favorable to corporate raiders and hostile bids, ${ }^{49}$ too suspicious of the motives of directors, ${ }^{\mathrm{s}}$ and too unresponsive to the legitimate interests of nonshareholder constituencies such as employees and communities. No American jurisdiction went further than Delaware and adopted rules, either by statute or judge-made law, that restrict takeover defenses more tightly than Delaware. No American jurisdiction has ever adopted a framework for takeover law based on the efficient market theory or gone farther than Delaware in that direction.

If anything, after 1985 there was a growing realization that the extreme simplicity of the world view of the anti-board partisans-that there was no place for any interference with the presumed "right" of shareholders to sell the company at any time to a bidder opposed by the board, and that directors should therefore be "passive instrumentalities"-was neither an accurate description of reality nor a desirable goal. Moreover, in 1987, the United States Supreme Court, which in 1982 had rejected states' efforts to regulate takeovers through socalled "first generation" statutes, effectively switched sides and endorsed "second generation" statutes in CTS Corp v Dynamics Corp of America. "The 1987 market "break," and the 1990 collapse of Drexel Burnham Lambert, the most prominent financier of hostile bids in the 1980s, further damaged the prestige and persuasiveness of the efficient market theory.

and intelligible"). See generally Roberta Romano, The Genius of American Corporate Law (AEI 1993).

49 See, for example, Ind Code Ann \$§ 23-1 to 35-1(f) (West Supp 2001) (Standards of Conduct for Directors), which rejects the Unocal compromise as being "inconsistent with the proper application of the business judgment rule under this article. Therefore, the general assembly intends ... to protect both directors and the validity of corporate action taken by them in the good faith exercise of their business judgment after reasonable investigation." When the Supreme Court upheld Indiana's control share acquisition statute in CTS Corp v Dynamics Corp of America, 481 US 69,94 (1987), the Court ushered in a new era in state activism regarding takeovers. See, for example, 805 ILCS 5/8.85 (West 1998) (stating that a board may consider the effect of congressional action on employees, supplies, and customers); NJ Rev Stat Ann § 14A:7-7 (West 2001) (stating that the judgment of the board is conclusive in issuing rights and options); NY Bus Corp Law $\S 717$ (b) (West 1986); Ohio Rev Code Ann § 1701.59(E) (West 1994 \& Supp 2001) (stating that a director may consider the interests of shareholders, employees, suppliers, and customers when determining what is best for the corporation).

50 Unocal seemed to assume that the perks of outside directorship are substantial enough to cause independent directors to be less trustworthy in making takeover-related decisions than garden-variety business decisions. See Unocal, 493 A2d at 954-55. I am aware of no research or evidence on this point. It is certainly not self-evident.

51481 US 69, 94 (1987) (holding that the Indiana control share acquisition statute was a legitimate exercise of state authority, and that it did not conflict with federal tender offer regulation). 
It is perhaps outside the terms of academic argument, but nonetheless suggestive, to recall the subsequent careers of the bidders whose takeover proposals were opposed by boards in some of the high profile cases of the 1980s. For example, the board of Macmillan, Inc. was harshly criticized by the Delaware courts for opposing Robert Maxwell's 1988 bid for the company. But in light of the revelations of dishonesty, corporate looting, and other wrongdoing that followed Maxwell's presumed suicide in 1991, does the Macmillan board now look quite so unreasonable in preferring a 20 cent per share lower bid from Maxwell's rival Henry Kravis? While the Maxwell and Macmillan transaction is perhaps the most thought-provoking example, is there anything in the subsequent business careers of such raider icons of the 1980s as Boone Pickens, Carl Icahn, Paul Bilzerian, and Robert Campeau that suggests that corporate law should have been redesigned to put these people in charge of important enterprises and large pools of assets?

In 1988, Delaware adopted its own "second generation" statute. This enactment is Delaware's only major legislative response to the takeover issue, and clearly represents a further rejection of the efficient market theory. Under Section $203,{ }^{52}$ directors have the statutory power effectively to block potential transfers of control to substantial shareholders by refusing to approve a transaction. While this power is not absolute, it can be overridden only by a very high "supermajority" of 85 percent of the shareholders; Section 203 is in effect a statutory pill that can be neutered by a tender offer that attracts 85 percent of the shares. Like the 1985 cases, Section 203 is another Delaware compromise, but clearly one that recognizes that directors should have a major role in determining the corporation's fate in a takeover situation.

Events of the 1990s have further demonstrated the wisdom of the Delaware compromise. The coercive, highly leveraged, and often destructive attributes of the 1980s takeover market have faded from view. Secure in their ability to resist hostile bids, directors have used this authority to enhance shareholder value. And directors can use this same power to resist a transaction they reasonably believe to be insuf-

528 Del Code Ann \$ 203 (1991).

53 But see In re Aquila, Inc, Shareholders Litigation, 2002 Del Ch LEXIS 5: In re Siliconix, Inc, Shareholders Litigation, 2001 Del Ch LEXIS 83. Though these two cases encourage boards of directors (by insulating them from shareholder litigation claims) to pass decisions on takeover proposals directly to shareholders, both cases involve special circumstances and do not indicate a departure from Delaware's general policies. Nothing in either decision purports to change the duties of directors in situations where board action is required. 
ficient or unduly speculative $e^{\text {st }}-\mathrm{a}$ power of no mean significance, wielded for the protection of the interests of shareholders and, indeed, every corporate constituency. Confirming the position I first advanced in 1979 in Takeover Bids in the Target's Boardroom, the American Law Institute-in Principles of Corporate Governance-endorsed Delaware's takeover jurisprudence as a model for the nation.

54 Former Chancellor Allen, Vice Chancellor Jacobs, and Vice Chancellor Strine of the Delaware Chancery Court make the following observation in their Article in this Symposium: "Judges suspect that it is relatively easy for management to hire an investment banker, and to coax a CFO to crank up earnings projections, that will justify the board's rejection of a higherpriced takeover offer in favor of continuing the status quo or approving a lower-priced friendly deal." William T. Allen, Jack B. Jacobs, and Leo E. Strine, Jr., The Great Takeover Debate: A Meditation on Bridging the Conceptual Divide, $69 \mathrm{U}$ Chi L Rev 1067, 1092 (2002). After forty-five years of advising companies and their boards of directors in connection with both unsolicited takeover proposals and friendly negotiated acquisitions, I am convinced that it is in connection with the latter, and not the former, that management and their investment banker advisors are frequently overly optimistic. That is why more than half the mergers that have taken place in the past thirty years did not meet expectations and resulted in a significant transfer of wealth from the shareholders of the acquirors to the shareholders of the acquirees. See Sanjai Baghat, Andrei Shleifer, and Robert W. Vishny, Hostile Takeovers in the 1980s: The Return to Corporate Specialization, Brookings Papers on Econ Activity: Microecon (1990); Michael C. Jensen and Richard S. Ruback, The Market for Corporate Control: The Scientific Evidence, $11 \mathrm{~J}$ Fin Econ 5, 22 (1983). The opposite is the case with unsolicited takeover bids. In the vast majority of cases-I am hardpressed to name more than one or two in my experience-the management of the targets and their investment bankers, warned by their lawyers that their analyses, deliberations, and final determination would be scrutinized in litigation, are quite conservative in their projections and valuations. I do not share the judges' skepticism. Further, it is worth noting that in addition to the high premia paid in hostile takeovers, the damage inflicted on the targets, see text accompanying notes $13-15$, raises costs and interferes with successful post-acquisition integration so that they are even more injurious to the shareholders of the acquirors than friendly acquisitions. My experience in several thousand acquisitions leads me to the conclusion that the acquisitions that make the most sense and generally benefit both sets of shareholders, and the economy as a whole, are "mergers of equals," in which there is no premium and both sets of shareholders share in the synergies and other benefits of the combination in accordance with their proportionate interests. If a radical change in the law relating to mergers is warranted, I would argue that protection against interlopers seeking to break up a merger of equals is where we should focus. If the academic critics of the business judgment rule and the pill do in fact believe that takeovers and mergers are beneficial to the economy, I would think that they would support such change.

55 See Principles of Corporate Governance: Analysis and Recommendations $\S 6.02$ at 405 (ALI 1994):

$\$ 6.02$. Action of Directors that Has the Foreseeable Effect of Blocking Unsolicited Tender Offers.

(a) The board of directors may take an action that has the foreseeable effect of blocking an unsolicited tender offer [ $\$ 1.39$ ], if the action is a reasonable response to the offer.

(b) In considering whether its action is a reasonable response to the offer:

(1) The board may take into account all factors relevant to the best interests of the corporation and shareholders, including, among other things, questions of legality and whether the offer, if successful, would threaten the corporation's essential economic prospects; and

(2) The board may, in addition to the analysis under $\$ 6.02(b)(1)$, have regard for inter- 
In the same vein, it warrants notice that Delaware's two major structural features with respect to takeover law-the poison pill and Section 203-have not given rise to significant case law since the Household case. While the Household Court announced in 1985 the standard-Unocal-under which pill decisions were to be reviewed, there have been only three Delaware Chancery Court decisions requiring a board of directors to redeem a pill, two of which were later disapproved by the Delaware Supreme Court in Time-Warner. ${ }^{\text {s6 }}$ The only case in which a board of directors was found to have breached its fiduciary duties in connection with its application of Section 203 involved the improper waiver of the protections of Section 203 by the directors of a majority-owned subsidiary. ${ }^{57}$ The absence of such case law strongly suggests that both the pill and Section 203 are being utilized responsibly by Delaware boards and that the system they uphold is a healthy one. ${ }^{5 s}$ After twenty years, I can confidently say that the pill has been used; it has not been abused.

ests or groups (other than shareholders) with respect to which the corporation has a legitimate concern if to do so would not significantly disfavor the long-term interests of shareholders.

(c) A person who challenges an action of the board on the ground that it fails to satisfy the standards of Subsection (a) has the burden of proof that the board's action is an unreasonable response to the offer.

(d) An action that does not meet the standards of Subsection (a) may be enjoined or set aside, but directors who authorize such an action are not subject to liability for damages if their conduct meets the standard of the business judgment rule [\$ 4.01(c)].

56 The Chancery Court decisions in City Capital Associates Ltd Partnership v Interco, Inc, 551 A2d 787 (Del Ch 1988), and Grand Metro PLC v Pillsbury Co, 558 A2d 1049 (Del Ch 1988), were disapproved by the Delaware Supreme Court in Time-Warner, 571 A2d at 1152-53 (referring to Interco's reading of the Unocal standard as "narrow" and "rigid"). The only other Chancery Court decision requiring a target to redeem a poison pill was in the context of a completed auction of the company in which the two highest bids were on the table and the court found that no corporate purpose would be served by maintaining a poison pill to preclude the possible consummation of a $\$ 90.25$-per-share bid in favor of a $\$ 90.05$ deal supported by the target. See Mills Acquisition Co v Macmillan Inc, 1988 Del Ch LEXIS 138, *56-57, revd on other grounds, 559 A2d 1261 (Del 1989).

57 In re Digex, Inc, Shareholders Litigation, 2000 Del Ch LEXIS 171, *112.

58 The work of Robert Daines demonstrates that Delaware's post-1985 legal regime has not reduced returns to shareholders. See Daines, Does Delaware Law Improve Value? at 26 (cited in note 46). As Professor Daines summarizes his conclusions:

Delaware corporate law improves firm value and facilitates the sale of public firms. Using Tobin's $Q$ as an estimate of firm value, I find Delaware firms are worth significantly more than similar firms incorporated elsewhere. The result is robust to controls for firm size, diversification, profitability, investment opportunity and industry. Delaware firms also receive significantly more takeover bids and are significantly more likely to be acquired. Firms with strong incentives to choose valuable legal regimes are likely to incorporate in Delaware when they go public. These results suggest that corporate law affects firm value.

Id (abstract). Professor Daines's study, while starting from the premise of the efficient market 
Nevertheless, for reasons that are not supported by history or practice, ${ }^{59}$ the academic community and activist investors have not been satisfied with the Delaware solution and the present state of the law. ${ }^{60}$ The leading spokesperson for doing away with the pill, Professor Ronald Gilson, argues that shareholders should be permitted to adopt a bylaw that repeals a poison pill previously adopted by the corporation and that prohibits the corporation from adopting a pill in response to a hostile takeover bid. ${ }^{61}$ Professor Gilson would go back to the 1979-82 debate and essentially come down on the side of the Rule of Passivity. Without the pill, there is no effective defense against a hostile takeover, and Professor Gilson would doom all targets to being acquired by a raider or a white knight. A full explication of Professor Gilson's thesis and my refutation are available in my response to his article. $^{62}$ It also should be noted that in a reply to my response, ${ }^{63}$ Pro-

theory, nonetheless shows none of the dysfunctional or shareholder-wealth-damaging effects complained of by others.

59 See, for example, Coates, $54 \mathrm{U}$ Miami L Rev at 7 (cited in note 43) (affirming that there is no evidence that the poison pill has ever detracted from shareholder economic welfare); J.P. Morgan \& Co, Poison Pills and Acquisition Premiums (May 2001) (studying 397 U.S. transactions from 1997-2000, representing all announced acquisitions of U.S. publicly traded companies in excess of $\$ 1$ billion (both deal and firm value), finding that the median takeover premium paid for companies that had a rights plan in place was 4 percent higher than for companies that did not have one. The study notes that a distorting factor during this time period was the influence of technology companies; premiums paid in transactions involving technology targets were actually higher at non-pill companies. The takeover premium difference at all nontechnology companies was 7.5 percent.); J.P. Morgan \& Co, Median Control Premiums: Pill v. No Pill (July 1997) (studying three hundred U.S. transactions from 1993 through 1997, representing all transactions over $\$ 500$ million in which a majority interest was purchased, finding that the median takeover premium paid for companies that had a rights plan in place was nearly 10 percent higher than for companies that did not have one. J.P. Morgan further found that in hostile deals during the period from 1988 through 1997, the takeover premium paid was 14 percent greater for companies with rights plans in place.); Georgeson Shareholder, Mergers \& Acquisitions: Poison Pills and Shareholder Value/1992-1996 (1997) ("Georgeson Study") (finding, in a study of 319 takeover transactions over $\$ 250$ million between 1992 through 1996, that premiums to acquire companies that had shareholder rights plans six months prior to the first bid were on average eight percentage points higher than premiums paid for target companies without rights plans); Robert Comment and G. William Schwert, Poison or Placebo? Evidence on the Deterrence and Wealth Effects of Modern Antitakeover Measures, 39 J Fin Econ 3, 31 table 4 (1995) (confirming premium results).

60 In 1984 , total United States merger and acquisition activity was $\$ 196$ billion, it grew to $\$ 1.7$ trillion in 2000, and with the market decline in 2001, fell to $\$ 800$ billion-still four times the 1984 volume. Thomson Financial Securities Data. Merger and acquisition activity as a percent of market capitalization has averaged 10 percent since 1985 and averaged 12 percent in 1998-2000. Goldman Sachs, (Jan 7, 2002). Clearly the pill and takeover defenses have not had an adverse effect on the volume of change of control transactions.

61 See Gilson, Unocal Fifteen Years Later at 3 (cited in note 6) (predicting the demise of "Delaware law's current pro-election, anti-market bias").

62 See Martin Lipton and Paul K. Rowe, Pills, Polls, and Professors, 27 Del J Corp L (forthcoming 2002).

63 Ronald Gilson, Lipton \& Rowe's Apologia for Delaware: A Short Reply, 27 Del J Corp L 
fessor Gilson essentially acknowledges that his fight is not against the pill's being used to support a "just say no" response to a hostile takeover bid, but instead against a theoretical construct that the pill permits a "just say never" defense. He argues that the marketplace, in the form of shareholder pressure on the board of directors, has prevented the pill from being an absolute bar to a takeover, and therefore the pill does not function as designed. As the creator and principal proponent of the pill, I think it fair to say that the pill was neither designed nor intended to be an absolute bar. It was always contemplated that the possibility of a proxy fight to replace the board would result in the board's taking shareholder desires into account, but that the delay and uncertainty as to the outcome of a proxy fight would give the board the negotiating position it needed to achieve the best possible deal for all the shareholders, which in appropriate cases could be the target's continuing as an independent company. The pill and the proxy contest have proved to yield the perfect balance, both hoped for and intended, between an acquiror and a target. A board cannot say "never," but it can say "no" in order to obtain the best deal for its shareholders." If Professor Gilson's price for entente cordiale is a concession that a "design flaw" in the pill forecloses it from being used to achieve the never-intended result of enabling a board of directors to totally and permanently ignore the will of the shareholders and "just say never," the Gilson Theatre of the Twenty Years' Pill Wars can now be closed.

A new participant in the debate, Professor John Coates, recognizing that Delaware would not embrace the Gilsonian views and would strike down the bylaw Professor Gilson proposes, has advanced three bylaws that he believes would accomplish the same purpose, yet might stand a better chance of passing the test of legality in Delaware. Ac Activist shareholder groups are presently attempting to implement variations of the Coates approach. Although discussion of the legality of

(forthcoming 2002).

64 See Kahan and Rock, 69 U Chi L Rev at 910 (cited in note 48) ("[T] he ultimate effect of the pill is akin to 'just say wait."').

65 See Coates and Faris, 56 Bus Law at 1327 (cited in note 7) ("[I]t seems inevitable ... that shareholder activists will design new forms of bylaw with a better chance of being upheld by the Delaware courts."). See also note 44.

66 See, for example, Providence Capital, Inc, press release (Sept 20, 2001), available online at $<$ http://providencecapitalnyc.com $>$ (visited Jan 31, 2002) (announcing a seminar on a Director Nomination By-law Amendment, in which board members would be disqualified from being renominated if they fail to abide by precatory shareholder votes to eliminate poison pills). Note, however, that these bylaws may not be legal. See Laurence A. Hamermesh, Corporate Democracy and Stockholder-Adopted By-Laws: Taking Back the Street?, 73 Tulane L Rev 409, 437 \& nn 123-124, 483 \& n 314 (1998) (asserting that bylaws addressing specific business decisions are invalid). Hamermesh argues that the "statutes creating general authority to adopt by-laws may not be construed to permit stockholders to adopt by-laws directly limiting the managerial power of 
these bylaws is outside the scope of this Commentary, there is a serious question of their validity, as even Professor Coates acknowledges-namely, that the bylaws are in essence conduct-regulating rather than qualification bylaws."

Professor Bebchuk, who in 1982 was an advocate of the Rule of Passivity, ${ }^{3}$ modified to permit the target's board to seek a white knight, now accepts the poison pill and acknowledges the right of the board of directors to deploy it in defense of a hostile takeover bid. However, he rejects the fundamental premise of Delaware law and the Household case that if shareholders are dissatisfied with the directors' response to a takeover bid, their remedy is to vote out the incumbent board and replace it with one that will redeem the pill and sell the corporation to the raider or a white knight. Rather, his solution is to change the law to provide that whenever a corporation becomes the target of a hostile bid, the board must submit it to a shareholder referendum. He proposes that if a majority of the outstanding

the board of directors." Id at 419 . He concludes that, in the short term, investors will continue to press forward with bylaw initiatives, but in the long term, state legislation will likely be enacted to limit stockholders' power to do so. Id at 492.

67 See Hamermesh, 73 Tulane L Rev at $425 \& \mathrm{n} 71$ (cited in note 66) (analogizing corporate bylaws to acts of a legislature). In a January 28,2002 , memorandum to me, Professor Coates disagreed with my interpretation of the effect of his bylaw proposals. Professor Coates wrote:

I don't agree our bylaw proposals are equivalent to Providence's approach, either legally or practically. I'm on the record that Providence's approach-linking director qualification to pill redemption-is likely illegal in Delaware. Our director qualification bylaw would leave pills intact, preserve the central role of boards in responding to hostile bids, and give management power to select directors from among a company's largest 25 shareholders. The bylaw would not even indirectly facilitate a hostile bid unless nearly all large shareholders supported a sale. In practical terms, the bylaw would encourage responsible long-term investing. In legal terms, the bylaw would allow long-term shareholders-at some cost and effort on their part-to improve the process by which they elect boards in the ordinary course, outside the context of hostile bids, and so is directly in line with Moran, Blasius, and other cases emphasizing the role of shareholder voting. As I don't see our bylaw proposals as resulting in elimination of defenses, I see no real tension between the proposals and my earlier work showing that empirical studies haven't proven defenses harmful to shareholder interests.

Memorandum from John Coates IV to Martin Lipton (Jan 28, 2002) (on file with author). I do not accept Professor Coates's explanation. Although his three proposed bylaws do not directly result in the "elimination of defenses," as did the first-generation bylaws (such as Professor Gilson's), his first two proposals are explicitly intended to facilitate takeovers, and the third-the director qualification bylaw - is intended to give shareholders a "voice" that is primarily valuable insofar as it enables the shareholders to facilitate takeovers as members of the board. Even the article itself is framed as presenting alternative means to achieve the same end as was intended by the first-generation bylaws.

68 See Bebchuk, 95 Harv L Rev at 1028 (cited in note 3) (arguing that facilitating bidding interests is desirable for target shareholders and society). 
shares vote in favor of the bid, the board must remove the pill and all other structural takeover defenses."

As originally proposed in 1982, and as approved in the Household decision, the pill contemplated that a board of directors could not ignore the will of the shareholders with respect to a takeover offer. ${ }^{10}$ The pill was structured so that it would not interfere with the right of the shareholders to vote to replace the board and would not impede a raider from instituting a proxy fight to replace the board." Professor Bebchuk acknowledges in his current work that the fact that the pill requires hostile bidders to prevail in a proxy contest - what he calls the "critical consequence of the pill"-is indeed desirable. ${ }^{n}$ However, he wants the decision in the form of a bidder-initiated referendum on the bid, and not on the composition of the board, and at whatever time a bidder determines.

69 See Bebchuk and Ferrell, 87 Va L Rev at 144 (cited in note 1) ("To enable shareholders to pass judgment on a bid, it is necessary to stop target management from preventing the bid from ever being considered by shareholders in the first place.").

70 "When the Household Board of Directors is faced with a tender offer and a request to redeem the rights, they will not be able to arbitrarily reject the offer." Household, 500 A2d at 1354.

71 See, for example, Account $v$ Hilton Hotel Corp, 780 A2d 245, 249 (Del 2001) ("[A] rights plan would not have the unauthorized effect of restricting stockholders' rights to conduct a proxy contest."), citing Household, 500 A2d at 1355-56. See also In re Gaylord Container Corp Shareholders Litigation, 753 A2d 462, 470 (Del Ch 2000) ("[T]he fact that a company has a poison pill in place is less significant because the proxy fight can operate as a substitute for a tender offer."); Stahl v Apple Bancorp, Inc, 1990 Del Ch LEXIS 121, *17 ("Thus, while the Rights Plan does deter the formation of proxy efforts of a certain magnitude, it does not limit the voting power of individual shares.").

72 Lucian Bebchuk and Oliver Hart, Takeover Bids vs. Proxy Fights in Contests for Corporate Control at 4, Harvard Olin Discussion Paper No 336 (first draft Feb 1999; last revised Oct 2001), available online at $<$ http://www.law.harvard.edu/programs/olin_center/> (visited Jan 31 , 2002).

73 Similarly, the European Commission's Committee of Company Law Experts has concluded that "a rule should be introduced, which allows the bidder to break-through mechanisms and structures which may frustrate a bid, as defined in the articles of association and related constitutional documents .... The threshold for exercising the break-through right should not be set at a percentage higher than $75 \%$ of the risk-bearing capital of the company." European Commission, Report of the High Level Group of Company Law Experts on Issues Related to Takeover Bids 7 (Jan 10, 2002), available online at <http://europa.eu.int/comm/internal_market/en/ company/company/news/hlg01-2002.pdf> (visited May 2, 2002). However, in explaining their conclusion, the European Commission's Committee of Company Law Experts noted in a recent report that U.S. boards of directors are subject to much greater pressure to maximize shareholder value than are their European counterparts. Id at 40-41. Among the factors cited in support of this proposition by the Committee of Company Law Experts are the following: U.S. boards of directors are judged by their performance in the capital markets; they are subject to pressure from institutional investors; their behavior is painfully public due to disclosure rules and media attention; they may be replaced in a successful proxy contest; and it is relatively easy for shareholders to bring derivative suits against them. Id. Further, the Committee argues that the existing U.S. antitakeover measures arose largely in response to a potential raider's ability to bid for only a portion of a company's outstanding shares; in Europe, a bidder is required to offer 
Professor Bebchuk's central position is that shareholders should have the right to vote to replace some or all of the directors or redeem a poison pill as soon as reasonably practical after a bid is made. Alternatively, he supports the enactment of bylaws that would limit the types of pills that the board may adopt, in order to achieve the same result. In effect, Professor Bebchuk would turn the clock back to Chancellor Allen's decision in City Capital Associates Ltd Partnership $v$ Interco, Inc, and then extend the holding in order to remove a staggered board in one election instead of several, or, more directly, to obviate the need for an election at all.

For the past year, proponents of Professor Bebchuk's referendum proposal have been citing the fourteen-month resistance by Willamette to a hostile takeover bid by Weyerhaeuser as an example of abuse of the pill and staggered board combination. Weyerhaeuser's first bid was $\$ 48$ per share, which it subsequently unilaterally raised to $\$ 50$ per share prior to commencing a proxy fight. Willamette's position was that Weyerhaeuser was attempting to acquire it at an inadequate price that did not reflect its true value. Willamette continued to resist after shareholders replaced a third of the board with nominees of Weyerhaeuser committed to a sale of the company and after 64 percent of the shares were tendered to the all-cash, all-shares offer. ${ }^{35}$ This gave the pill traducers their best argument-that the combination allows a determined board to deny the will of the shareholders not for one year, but for two. However, this argument evaporated after Weyerhaeuser increased its offer from $\$ 50$ per share to $\$ 55$ per share and finally to $\$ 55.50$ per share, which the Willamette board finally accepted as being in the best interests of its shareholders. ${ }^{76}$ The Weyerhaeuser-Willamette deal is no less than a shining example of how a staggered board and poison pill operate to the benefit of shareholders. The agreed-upon price of $\$ 55.50$ represents a 16 percent increase

to purchase all outstanding shares at an equitable price. Id at 41.

74551 A2d 787 (Del Ch 1988).

75 See Jim Carlton and Robin Sidel, Willamette Agrees to Be Bought by Weyerhaeuser, Wall St J A3 (Jan 22, 2002). See also Stanley Holmes, It's Time for Willamette to Give in to Weyerhaeuser, Bus Week 30 (Jan 14, 2002) (stating that the merger "makes good strategic sense" and calling on Willamette to give up the takeover fight).

76 See Darrell Hassler, Weyerhaeuser to Buy Willamette for $\$ 7.78$ Billion in Cash, Debt, Bloomberg News (Jan 21, 2002); Bill Virgin, Weyerhaeuser Finally Wins; Willamette Gives In, Agrees to Be Bought by Rival for $\$ 55.50$ a Share, Seattle Post-Intelligencer A1 (Jan 2, 2002) (including a timeline of events in Weyerhaeuser's bid for Willamette).

77 BTR Corporation's 1990 acquisition of Norton Corporation also illustrates how a staggered board affords a board of directors the leverage and time it may need in order to negotiate effectively with a potential acquiror. In BTR-Norton, shortly before the annual meeting of Norton at which BTR's nominees were up for election, Governor Dukakis signed a bill amending the Massachusetts corporation law to mandate that all Massachusetts corporations have a stag- 
over Weyerhaeuser's initial bid, and an 11 percent increase in deal value even after the conclusion of the first proxy fight. Those who would credit shareholder choice for the outcome overlook the fact that in the absence of the staggered board and poison pill, Willamette shareholders would have "chosen" $\$ 48$ per share before they ever had the opportunity to receive $\$ 55.50$. $^{78}$

Willamette is typical of the experience of the past twenty years, during which very few companies have remained independent after a tender offer combined with a proxy fight to replace the board. The largely theoretical possibility of continued resistance after loss of a proxy fight that worries Professor Bebchuk and his followers does not in any way warrant a change in basic corporate law, which has long permitted shareholders to enjoy a staggered-board charter that protects against changes in management predicated on short-term events. ${ }^{79}$ There are strong policy reasons to assure that management has sufficient time to demonstrate the validity of its strategic planindeed, I have argued that this period should be five years, with a referendum on the management's performance and the possibility of a hostile takeover only at the quinquennial election.

There have been a number of instances in which an unsolicited bid has been coupled with a proxy fight to remove the target's board and replace it with a board committed to redeeming the target's pill."

gered board unless the board determines otherwise. Due to this timely intervention, the Norton board was able to negotiate an additional $\$ 15$ per share for its shareholders.

78 Fifty-one percent of the outstanding shares had been tendered into Weyerhaeuser's $\$ 48$ per-share offer as of the February 2, 2001 expiration date. See Weyerhaeuser Extends an Offer, NY Times C14 (Feb 2, 2001).

79 Of the five-thousand-plus U.S. public companies that responded to the 2001-2002 NACD Public Company Governance Survey, 57 percent have a classified board. See National Association of Corporate Directors, 2001-2002 NACD Public Company Governance Survey 14 (Nov 2001). Further, the survey reveals that "[n]early three-quarters of the initial public offering companies tracked in 2001 had classified boards." Id. Also, the pill has been adopted by thousands of public companies and has become an essential, commonplace element of the fabric of corporate governance, with no adverse impact on share prices or merger activity. Academic prescriptions for change would upset widespread and settled expectations and practices, and therefore should carry a particularly heavy burden of persuasion. I find nothing in the recent study undertaken by Professors Bebchuk, Coates and Subramanian that warrants such a change. See Lucian Arye Bebchuk, John C. Coates IV, and Guhan Subramanian, The Powerful Antitakeover Force of Staggered Boards: Theory, Evidence \& Policy, 54 Stan L Rev (forthcoming 2002).

80 See Lipton and Rosenblum, 58 U Chi L Rev at 224-29 (cited in note 14) ("The five-year period between election meetings affords directors and managers some measure of freedom from the short-term focus now imposed on them by institutional stockholders' pressure for quarterly results and the ever-present takeover threat."). See Allen, Jacobs, and Strine, 69 U Chi L Rev at 1096-1100 (cited in note 54), for a modified form of this proposal that has been advanced for discussion.

81 The poison pill has decisively shifted the battle for corporate control from the arena of the coercive tender offer to that of the proxy contest. When confronted with a poison pill, a hostile suitor may be forced to make its case by means of a proxy solicitation if it wishes to persuade 
In some cases, the target was acquired by the original bidder, and in others, the target sought a white knight and was acquired at a higher price than that offered by the raider that initiated the process. In very few instances has a target with a staggered board suffered a firstround loss - had a third of the board replaced with the raider's nominees-and continued to refuse to surrender its independence. In all other cases, after a first-round loss, or even before, when it became clear that the shareholders would vote to replace a third of the board, the target negotiated a deal. In light of this experience, there does not appear to be any compelling need to change the law to mandate a shareholder referendum whenever a raider demands it.

By contrast, Professor Bebchuk's proposal carries with it significant dangers. As a practical matter, his proposal, like Professor Gilson's and like the 1981 Rule of Passivity proposal, would put a "For Sale" sign on all public corporations. Though the difference between a bid-and-referendum and a bid-and-proxy fight may be seen as one of degree, a referendum would create the critical problem of an open invitation for unsolicited bids. The acquiror would have the assurance of a vote on the bid, with little chance for the target to do anything other than declare an auction. Further, the costs of operating as if it were always for sale would be highly detrimental to a company. In general, a company that becomes the target of an unsolicited takeover bid must institute a series of costly programs to protect its business during the period of uncertainty as to the outcome of the bid. To retain key employees, in the face of the usual rush of headhunters seeking to steal away the best employees, expensive bonus and incentive plans are put in place. To placate concerned customers and suppliers, special price and order concessions are granted. Communities postpone or reconsider incentives to retain facilities or obtain new facilities. The company itself postpones major capital expenditures and new strategic initiatives. Creditors delay commitments and seek protection for outstanding loans. All of this imposes enormous costs on the target, which are not recovered no matter what the outcome of the takeover bid; ${ }^{\mathrm{s}}$ if the bidder is successful, the bidder and its shareholders bear

target shareholders that it is truly in their best interests to accept the offer. In addition to Weyerhaeuser-Willamette, other well-known examples are Georgia-Pacific Corporation's 1989 battle to acquire Great Northern Nekoosa Corporation, AT\&T's 1990 fight to acquire NCR, and IBM's acquisition of Lotus Development Corporation in 1995. In each case, the target board resisted a takeover, the acquiror commenced or announced the intention to commence a proxy contest, and the merger ultimately was consummated at a significantly higher price per share than that initially offered by the acquiror.

82 See, for example, Simon London, Secrets of a Successful Partnership, Fin Times (Feb 6, 2002) ("Mergers create uncertainty. Top salespeople become recruitment targets for rival companies. Redundancies damage morale. Customers are sensitive to signs that product or service 
these costs; if the target remains independent, the target and its shareholders bear them. The poison pill alleviates some, but not all, of these concerns and related costs. To change the law to remove the protections of the pill and not protect the target against these costs is unthinkable.

Professor Bebchuk's attempt to draw support from the decision of the EU to adopt a referendum-type regulation of unsolicited takeover bids is not well-founded. The EU specifically recognizes that its approach is based on a dramatically different set of economic conditions from those in the U.S. ${ }^{* 3}$ Further, the EU approach parallels closely the "no frustration" of bids approach of the U.K. Takeover Panel. There is no evidence that corporate performance and corporate governance in the U.K. are superior to that in the U.S. Indeed, it is universally recognized that that is not the case. ${ }^{84}$

Professor Bebchuk's proposal also raises fundamental issues of inconsistency with the existing corporate law allocation of responsibility between the shareholders and the board of directors. Professor Bebchuk would permit either a takeover bid combined with a referendum or a merger proposal that bypasses the target's board and is submitted directly to the target's shareholders. He would permit both cash and securities to be offered. No new financial, economic, or jurisprudential reason is advanced to support this radical change in the law. As matters now stand, it is an essential part of the statutory framework of Delaware law and of most, if not all, of the other states that both the directors and shareholders agree to a sale of the company before it can occur. In short, Delaware law requires that the board make a considered determination of the fairness of a bid before referring to shareholders the question of whether to keep the pill or other takeover protections in place. Under the Delaware statute, there is no contemplation of a control change unapproved by a board of directors. The "shareholder choice" provided by the statute is the right to choose representatives periodically, not the right of perpetual selfgovernance through instant polls or plebiscites. Directors have a duty

quality is slipping.").

83 See note 73.

84 The Committee of Company Law Experts recognizes that it is in effect hanging a "For Sale" sign on all EU public companies and that EU takeover rules will be virtually the opposite of those in the United States. The Committee believes that, at this stage of the EU markets and company consolidation, its recommendations-not the U.S. approach-are what is right for the EU. There is no doubt that, when the EU rules go into effect, there will be a significant increase in EU takeover activity. See Report of the High Level Group of Company Law Experts at 38-44 (cited in note 73).

85 Except for a "short-form merger" involving a 90 percent owned subsidiary. See 8 Del Code Ann $§ 253$ (1991 \& Supp 1999). 
to insure that the shareholders get a fair price, and "shareholder choice" independent of the board is not part of the law of mergers and acquisitions. The shareholders' right is to elect or replace the board of directors or to accept or reject a board recommendation.

As the law now stands, when faced with a takeover bid, a board has the duty to determine whether such bid is at a fair price and in the shareholders' best interests. ${ }^{85}$ This is not a burden to be taken lightly. Under Unocal and Unitrin $v$ American General Corp ${ }^{87}$ a board of directors may not merely "assert" that the underlying long-term value of the corporation exceeds the bid on the table; ${ }^{8 s}$ in the two cases in which a "just say no" defense was actually tried in court, the directors were required to show, through detailed presentations and expert testimony, that their position was reasonable and based on appropriate information. If a board either does not believe the takeover bid to be in the best interests of the shareholders, or is unable to make such a decision, it may not, consistent with its fiduciary duty under Van Gorkom, Household and Quickturn Design Systems, Inc $v$ Shapiro ${ }^{\circ} /$ Mentor Graphics Corp v Quickturn Design Systems, Inc, ${ }^{91}$ redeem the pill to permit the bid to go forward. It is inconsistent with existing Delaware law for a board, absent a board decision that the bid is fair, to delegate to shareholders in a referendum the fiduciary decision of whether to leave the pill or other takeover protections in place.

There is simply no reason to take the diametric turn in the law urged by Professor Bebchuk. And even if there were, Professor Bebchuk drastically underestimates the number and complexity of the conditions that would need to be applicable to such a referendum in order to protect the corporation and its shareholders from abusive bids. First, there would have to be assurance that the purpose of the bid is to acquire the target rather than to put it in play to profit from a topping bid. This could be accomplished by requiring that the bid rep-

86 See Van Gorkom, 488 A2d at 875 ("A substantial premium may provide one reason to recommend a merger, but in the absence of other sound valuation information, the fact of a premium alone does not provide an adequate basis upon which to assess the fairness of an offering price.").

87651 A2d 1361 (Del 1995) (applying Unocal standard to the board's stock purchase plan).

88 Professor Gilson appears to misunderstand the substantive nature of the directors' duty to consider a takeover bid. See Gilson, Unocal Fifteen Years Later at 13-14 (cited in note 6) ("[T]he Delaware Supreme Court's analysis reduces functionally to a preference that control contests be resolved through an election, rather than a market.").

89 See Moore $v$ Wallace, 907 F Supp 1545, 1549 (D Del 1995) (noting the three day preliminary injunction record and the voluminous record); Amanda Acquisition Corp v Universal Foods Corp, 708 F Supp 984, 1008-16 (E D Wis 1989).

90721 A2d 1281 (Del 1998).

91789 A2d 1216 (Del Ch 2001). 
resent a premium over the current market price equal to not less than the average of recent comparable acquisition premiums as set forth in an opinion of a recognized financial advisor. Here there would also be two subsidiary issues: Should the target be able to dispute the premium analysis, and should the referendum be denied to a bidder that has acquired more than 1 percent of the outstanding shares of the target within the twelve months prior to the bid?

Second, the bid could not be overly conditional. Here the principal question is the degree of material adverse change that would warrant the bidder's terminating the bid and walking away. This is a matter that has recently been contested in connection with negotiated takeovers. ${ }^{\text {2 }}$ To protect the target and its shareholders, the adverse change condition would have to be triggered only for truly material, unforeseen events that have a long-term impact and that are company-specific as distinguished from industry-wide or macroeconomic events.

Third, the obviously necessary condition that the bidder obtain regulatory approval raises another difficult issue: How far should the bidder have to go to obtain regulatory approval, and how much time should be allowed for it to do so? Since the bidder initiates a unilateral process that it knows will be very disruptive and costly to the target, the bidder would have to be required to use its best efforts, including agreeing to any divestitures, business restrictions, or expenditures that are necessary to obtain regulatory approval. If it failed to do so, the bidder would be obligated to the target for liquidated damages in an amount equal to a percentage of the offer price sufficient to compensate for the damages caused by the disruption." This could, for ex-

92 Two of the most highly publicized transactions of 2001 include Tyson Foods's acquisition of IBP, see, for example, Herbert Henryson, IBP v. Tyson Teaches Valuable Lessons, NY L J 1 (July 26, 2001), and WPP Group's acquisition of Tempus Group, see, for example, Jean Eaglesham, Ruling Sets High Hurdle for 'MAC Clauses': The Takeover Panel Has Left Little Room for Manoeuvre, Fin Times 24 (Nov 7, 2001). Both Tyson and WPP tried to walk away from their deals on the basis of material adverse change conditions in the merger agreements. In each case, a court ruled that the intervening events cited by the acquiror did not constitute sufficient justification for terminating the merger agreement and ordered that the merger be consummated.

93 Indeed, after the Tyson case, more attention than ever is being paid to material-adversecondition provisions in merger agreements. "What might have been boilerplate before may now be a point of negotiations." Jaret Seiberg, A Legal Beef, Tyson's Big MAC Attack on IBP Reshaped $M \& A L a w$, Daily Deal 15 (Jan 18, 2002) (quoting Lawrence Hamermesh).

94 The ill-fated attempt by General Electric to acquire Honeywell International in 2001 is a situation that received a great deal of attention in which the failure to obtain required regulatory approvals doomed a merger. GE made an unsolicited $\$ 55$-per-share proposal to Honeywell while the Honeywell board of directors was concluding a special meeting called to approve an extensively negotiated merger with United Technologies at $\$ 50$ per share. See, for example, Neal St. Anthony, Honeywell's Path to Deal Now Subject to Question, Star Trib 1D (Oct 29, 2000). The GE 
ample, equal 5 percent of the aggregate bid. If the time period during which regulatory approval is being sought is more than six months, and thereafter the raider fails to get the approval, the liquidated damages could be increased by, say, one percent per month to compensate for the greater damage inflicted on the target by the longer period of disruption from uncertainty as to the future of the target. Even with further compensation, it would be necessary to specify a final expiration date that could not be greater than, say, nine months. A related issue is the limitation on the bidder's ability to negotiate with regulators, who would be aware of the strictures imposed by the statutory referendum procedure.

A fourth set of issues involves the proposed consideration. Where all or part of the bid consideration is cash, the bidder would be required to furnish assurance that it has the cash on hand or a loan commitment from a major financial institution that is not qualified by a material adverse change condition that is different from the material adverse change condition in the bid.

Where all or part of the bid consideration is securities, the bidder would be required to make the bid through a registered securities dealer. The securities dealer would have "underwriter" liability under Section 11 of the Securities Act ${ }^{\text {s }}$ and would be expected to perform customary due diligence. Underwriter's liability and due diligence are not perfect safeguards, but they represent the minimum protection that should be afforded to the target's shareholders against the pitfalls of Professor Bebchuk's argument that the market effectively determines the value of the bid to the target's shareholders, who need only compare the pre-bid share price and the value of the bid. ${ }^{96}$ After all, in almost every case, it would be impossible for all the target's shareholders to convert all the securities received in the bid into cash at the price on the day the tender offer is consummated. Moreover, shareholders lack information that careful due diligence might reveal; a year ago, for example, Enron stock providing a 20 percent or better

merger agreement was signed within two days of the proposal's having been made. But though the U.S. Department of Justice would have permitted the merger, the European Competition Commission rejected GE's divestiture proposal as insufficient, and the parties ultimately canceled their merger agreement. See, for example, Neal R. Stoll and Shepard Goldfein, A Tale of Two Regulators, NY L J 3 (July 17, 2001). Upon termination of the merger agreement, GE agreed to pay Honeywell $\$ 100$ million to cover expenses related to the merger. See Honeywell International; Merger with GE Off, Appliance Manufacturer 18 (Nov 1, 2001). However, on October 2,2001, the day that GE and Honeywell announced the termination of their merger agreement, Honeywell stock closed at $\$ 38.05$ per share, 30 percent lower than the $\$ 55$ per share value of the GE deal and a total of more than $\$ 13$ billion lower than the GE bid, and more than $\$ 9$ billion lower than the United Technologies bid.

9515 USC $\$ 77 \mathrm{k}$ (1994).

96 See Bebchuk and Hart, Takeover Bids vs. Proxy Fights at 30 (cited in note 72). 
premium would have been considered a "great deal" by the shareholders of most target companies."

Bidders and the banks that finance and advise them will undoubtedly have trouble with these protections for the target and its shareholders. The difficulty of achieving an appropriate balance between the interests of a bidder and those of the target and its shareholders in designing such a bid and referendum structure illustrates that mergers, acquisitions, takeovers, and proxy fights and the legal rules applicable to them are complex, with many interdependent variables. As Professors Marcel Kahan and Edward Rock demonstrate in their current work, the relationship between corporate law and private ordering is highly dynamic, with each change resulting in numerous and often unforeseen responses. That is why, instead of a system of inflexible statutory rules, we have developed a system of negotiation-with the target board and the bidder as the primary negotiating counterparties. It is important to preserve the board's role as the best negotiator on behalf of the shareholders and not leap headlong into a new regime that has the potential to be seriously disruptive to business and the economy. But to be an effective negotiator-and the record shows that, on balance, boards have been ${ }^{\text {s9 }}$ - the board needs the fundamental power of any successful negotiator: the ability to "just say no" and walk away. The poison pill provides that power, which is why the pill is legal and why it enables directors to do their job effectively.

\section{CONCLUSION}

I developed the poison pill to protect against tender offers structured by raiders with terms that were inimical to the interests of shareholders, or which under certain circumstances would become inimical to shareholders. I put that tool in the hands of the board of directors as the only corporate organ that could act to protect both the corporation and the shareholders, with those actions subject to the power of a court to ensure that they met the business judgment rule test. As the foregoing discussion of the type of conditions that would be necessary to protect targets and their shareholders in a referendum regime demonstrates, the shareholders would be at a serious disadvantage if they did not have such statutory conditions or the board to negotiate terms on their behalf.

97 A comprehensive summary of Enron's dramatic collapse is set forth in A Chronology of Enron's Recent Woes, Wall St J C12 (Jan 16,2002).

98 See Kahan and Rock, 69 U Chi L Rev at 900-01 (cited in note 48).

99 See Georgeson Study (cited in note 59). 
As the pill approaches its twentieth birthday, it is under attack from three groups of professors, each advocating a different form of shareholder poll, but each intended to eviscerate the protections afforded by the pill. The Gilsonians urge the shareholders to approve a bylaw amendment invalidating the pill; the Coatesites would have the shareholders amend bylaws to accomplish the equivalent of invalidating the pill; and the Bebchukers would preserve the pill just long enough for the shareholders to invalidate it in a concurrent tender offer and referendum. Each of these three schools makes a strenuous effort to distinguish itself from the other two and to deny that it advocates a radical change in the law. Each also exalts shareholder democracy and choice: Gilsonians and Coatesites ex ante, and Bebchukers ex post. None of the three presents any real evidence to support the assertion that its approach is better than the others, and none addresses the cardinal issue of the cost to corporations and the economy as a whole if corporations are stripped of their takeover defenses and are at all times for sale.

Upon reflection, I think it fair to conclude that the three schools of academic opponents of the pill are not really opposed to the idea that the staggered board of the target of a hostile takeover bid may use the pill to "just say no." Rather, their fundamental disagreement is with the theoretical possibility that the pill may enable a staggered board to "just say never." However, as the recent Willamette situation and almost every other in which a takeover bid was combined with a proxy fight show, the incidence of a target's actually saying "never" is so rare as not to be a real-world problem. While each of these professors' attempts to undermine the protections of the pill is argued with force and considerable logic, none of their arguments comes close to overcoming the cardinal rule of public policy-particularly applicable to corporate law and corporate finance-"If it ain't broke, don't fix it." 


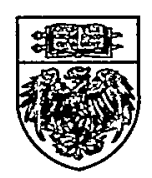

